\title{
Reply to Letter to the Editor to Maternal vitamin D status during pregnancy in Europe : the two sides of the story
}

\section{Hauta-alus, H. H.}

2017-09

Hauta-alus , H H , Holmlund-Suila , E M , Andersson , S, Mäkitie , O M \& Viljakainen , H T 2017 , ' Reply to Letter to the Editor to Maternal vitamin D status during pregnancy in Europe : the two sides of the story ' , European Journal of Nutrition , vol. 56 , no. 6 , pp. 2209-2210 . https://doi.org/10.1007/

http://hdl.handle.net/10138/243749

https://doi.org/10.1007/s00394-017-1452-9

publishedVersion

Downloaded from Helda, University of Helsinki institutional repository.

This is an electronic reprint of the original article.

This reprint may differ from the original in pagination and typographic detail.

Please cite the original version. 


\title{
Reply to Letter to the Editor to Maternal vitamin D status during pregnancy in Europe: the two sides of the story
}

\author{
Hauta-alus $\mathrm{HH}^{1} \cdot$ Holmlund-Suila $\mathrm{EM}^{1} \cdot$ Andersson $\mathrm{S}^{1} \cdot$ Mäkitie $^{\mathbf{O}} \mathbf{M}^{1,2}$. \\ Viljakainen HT $^{2}$
}

Published online: 24 April 2017

(C) Springer-Verlag Berlin Heidelberg 2017

We thank Karras et al. [1] for their interest towards our results which indicated that public health policies can be successful in ensuring vitamin D sufficiency (25-hydroxyvitamin $\mathrm{D}[25(\mathrm{OH}) \mathrm{D}) \geq 50 \mathrm{nmol} / \mathrm{l}]$ in pregnant women [2]. We agree that an adequate intake of vitamin $\mathrm{D}$ is highly relevant in maintaining sufficient maternal vitamin D status. The Finnish national guidelines for vitamin D food fortification and recommendations for vitamin D supplementation could be adapted in several other countries where maternal vitamin D deficiency is a concern. Along with the extensive fortification of dairy products and dietary fats, vitamin D deficiency was efficiently prevented with daily supplementation of merely $10 \mu \mathrm{g}$ [2]. We would, therefore, be cautious in increasing the recommended supplementation to $4000 \mathrm{IU} / \mathrm{d}(=100 \mu \mathrm{g} / \mathrm{d})$ [1]. Moreover, the optimal $25(\mathrm{OH}) \mathrm{D}$ concentration is still under debate, and the potential adverse effects of high $25(\mathrm{OH}) \mathrm{D}$ concentrations need to be avoided. According to the Institute of Medicine, 25(OH) D concentrations above $125 \mathrm{nmol} / \mathrm{l}$ might be harmful [3]. As long as the optimal $25(\mathrm{OH}) \mathrm{D}$ for pregnant women and newborn children remains unclear, public health recommendations should not advocate excessive vitamin D supplementation. In fact, we have reported a positive

This Reply refers to a Letter to the Editor available under: doi:10.1007/s00394-017-1451-x.

This Letter to the Editor refers to the article available at doi:10.1007/s00394-017-1417-z.

Viljakainen HT

heli.viljakainen@helsinki.fi

1 Children's Hospital, University of Helsinki and Helsinki University Hospital, Helsinki, Finland

2 Folkhälsan Research Center, Helsinki, Finland association between $25(\mathrm{OH}) \mathrm{D}$ concentration and inflammatory biomarkers in cord blood in vitamin D sufficient population [4]. Although the clinical importance of this cross-sectional finding remains unclear, a possibility for U-shaped relationship between $25(\mathrm{OH}) \mathrm{D}$ and the inflammatory state of a newborn could not be abandoned.

In Finland, vitamin D food fortification has been proven to be efficient in increasing the vitamin D intake in adult population resulting in a decrease in vitamin $\mathrm{D}$ deficiency [5]. The recommended use of vitamin D supplementation during pregnancy has also been well adapted. These public health policies have, in our country, been sufficient to improve maternal and newborn vitamin D status. The coming years will show how this translates to well-being of the mothers and their children. We agree with Karras et al. that prospective randomized studies are needed. While these results are awaited, research to define an optimal vitamin $\mathrm{D}$ status in all age groups should continue. It may well be that future findings will allow us to further increase the recommendations, but until then, caution should be exercised. At population level, the emphasis should be in achieving a sufficient maternal vitamin D status by both food fortification and with moderate dose of supplemental vitamin D.

\section{References}

1. Karras SN, Wagner CL, Angeloudi E, Kotsa K (2017) Maternal vitamin D status during pregnancy in Europe: the two sides of the story. Eur J Nutr. doi:10.1007/s00394-017-1451-x

2. Hauta-alus HH, Holmlund-Suila EM, Rita HJ, Enlund-Cerullo M, Rosendahl J, Valkama SM, Helve OM, Hytinantti TK, Surcel HM, Makitie OM, Andersson S, Viljakainen HT (2017) Season, dietary factors, and physical activity modify 25-hydroxyvitamin D concentration during pregnancy. Eur J Nutr. doi:10.1007/ s00394-017-1417-z 
3. Ross AC, Manson JE, Abrams SA, Aloia JF, Brannon PM, Clinton SK, Durazo-Arvizu RA, Gallagher JC, Gallo RL, Jones G, Kovacs CS, Mayne ST, Rosen CJ, Shapses SA (2011) The 2011 report on dietary reference intakes for calcium and vitamin D from the Institute of Medicine: what clinicians need to know. J Clin Endocrinol Metab 96:53-58

4. Rosendahl J, Holmlund-Suila E, Helve O, Viljakainen H, Hautaalus H, Valkama S, Enlund-Cerullo M, Hytinantti T, Tervahartiala
T, Sorsa T, Makitie O, Andersson S (2017) 25-hydroxyvitamin D correlates with inflammatory markers in cord blood of healthy newborns. Pediatr Res. doi:10.1038/pr.2017.9

5. Raulio S, Erlund I, Männistö S, Sarlio-Lähteenkorva S, Sundvall J, Tapanainen H, Vartiainen E, Virtanen S (2016) Successful nutrition policy: improvement of vitamin D intake and status in Finnish adults over the last decade. Eur J Public Health. doi:10.1093/eurpub/ckw154 